Details of patients with pulmonary hypertension in systemic lupus erythematosus

\begin{tabular}{|c|c|c|c|c|c|c|}
\hline $\begin{array}{l}\text { Case } \\
\text { No }\end{array}$ & $\underset{\text { (years) }}{\text { Age }}$ & Sex & $\begin{array}{c}\text { Raynaud's } \\
\text { phenomenon }\end{array}$ & $\begin{array}{c}\text { Lupus } \\
\text { anticoagulant }\end{array}$ & Vasculitis & $\begin{array}{c}\text { Pulmonary } \\
\text { artery } \\
\text { pressure } \\
(\mathrm{mm} \mathrm{Hg})\end{array}$ \\
\hline $\begin{array}{l}1 \\
2 \\
3 \\
4 \\
5 \\
6\end{array}$ & $\begin{array}{l}47 \\
41 \\
31 \\
19 \\
25 \\
21\end{array}$ & $\begin{array}{l}F \\
F \\
M \\
M \\
F \\
F\end{array}$ & $\begin{array}{l} \pm \\
- \\
+ \\
+ \\
+\end{array}$ & $\begin{array}{l}+ \\
+ \\
+ \\
+ \\
+\end{array}$ & $\begin{array}{l}+ \\
+ \\
\vdots \\
+ \\
-\end{array}$ & $\begin{array}{r}60 / 25 \\
135 / 25 \\
44 / 20 \\
55 / 25 \\
70 / 40 \\
80 / 40\end{array}$ \\
\hline
\end{tabular}

had Raynaud's phenomenon (though this was mild in all three), raising the possibility of vasospasm as an aetiological factor.

Another possible cause of pulmonary hypertension in our patients was vasculitis. Acute inflammation of small pulmonary arteries and arterioles has been found at necropsy in patients with systemic lupus erythematosus. In our series vasculitic lesions were noted in cases 1 3 , and 5 and one patient (case 4) developed a vocal cord palsy that may have been vasculitic in origin. Our data do not, however, suggest a major pathogenetic role for vasculitis.

Platelet dysfunction has recently been suggested as another possible aetiological factor in pulmonary hypertension in systemic lupus erythematosus. This was not, however, explored in our patients.

Thromboembolic disease is a well recognised cause of pulmonary hypertension, but recurrent small thromboemboli or in situ thrombosis may be easily overlooked clinically. A hypercoagulable state is occasionally seen in systemic lupus erythematosus and has been associated with the presence of a lupus anticoagulant, which has been found in up to $23 \%$ of patients with the disease. ${ }^{3}$ This antibody, which may be detected in either the IgG or IgM fraction of the serum, paradoxically prolongs kaolin partial thromboplastin time in vitro. It has also been associated with an increased risk of spontaneous abortion, thrombocytopenia, cerebral lupus, and a biological false positive result on testing for syphilis. ${ }^{4}$ Lupus anticoagulant was detected in five of our six patients (table), two of whom had a history of venous thrombosis. The remaining patient was immunosuppressed, and this might have accounted for the negative test result. It is interesting to speculate on the possible pathogenetic role of this anticoagulant in view of its association with thrombosis, and to suggest that its presence may perhaps be related to the development of intrapulmonary microthrombosis with consequent pulmonary hypertension. Twenty years ago Sleeper et $a^{5}$ noted that, of their series of 10 patients with primary pulmonary hypertension, three had false positive serological reactions to tests for syphilis, and this perhaps may have indicated the presence of lupus anticoagulant. Studies of this association are now in progress.

We are grateful to Dr D D Gibbs, The London Hospital, for permission to report on one of his patients.

${ }^{1}$ Kramer N, Perez H. Pulmonary hypertension in systemic lupus erythematosus: report of four cases and review of literature. Semin Arthritis Rheum 1981;11:177-81.

2 Walcott G, Burchell HB, Brown AL. Primary pulmonary hypertension. Am 7 Med 1970;39:70-9.

${ }^{3}$ Mueh JR, Kenneth D, Herbst MD, Rapaport SI. Thrombosis in patients with the lupus anticoagulant. Ann Intern Med 1980;92:156-9.

4 Byron MA. The clotting defect in systemic lupus erythematosus. In: Hughes GRV, ed. Clinics in rheumatic diseases. Vol 8. No 1. Philadelphia: WB Saunders, 1982:137-51.

${ }^{5}$ Sleeper JC, Orgain ES, McIntosh HD. Primary pulmonary hypertension: review of clinical features and pathologic physiology with a report of pulmonary haemodynamics derived from repeated catheterisation. Circulation $1962 ; 26: 1358$.

(Accepted 27 fune 1983)

Royal Postgraduate Medical School, Hammersmith Hospital, London W12 9HS

R A ASHERSON, MB, FCP(SA), visiting colleague

C G MACKWORTH-YOUNG, MA, MRCP, registrar

$M$ L BOEY, MMED, honorary research fellow

R G HULL, MB, MRCP, research fellow

A SAUNDERS, MB, BS, senior house officer

A E GHARAVI, MD, research fellow

G R V HUGHES, MD, FRCP, consultant physician

Correspondence to: Dr G R V Hughes, Rheumatology Unit, Hammersmith Hospital, London W12 9HS.

\section{Pregnancy complicated by gestational trophoblastic disease in a renal transplant recipient}

Fertility may return after renal transplantation. Several normal and abnormal pregnancies have been reported. ${ }^{1}$ We can find no report of gestational trophoblastic disease arising de novo in a pregnant renal transplant recipient and therefore describe such a case.

\section{Case report}

A 22 year old woman developed hypertension and uraemia from presumed chronic pyelonephritis in 1979. There was no evidence of autoimmune disease. She was maintained with haemodialysis until May 1981, when she received a cadaveric renal transplant. Immunosuppressive treatment was given as prednisolone and azathioprine. Four rejection episodes were each treated with high dose pulses of methylprednisolone, and after the third episode continuous low dose cyclophosphamide (30 mg daily) was added for three months. Six months after transplantation her serum creatinine concentration was $110 \mu \mathrm{mol} / 1(1 \cdot 2 \mathrm{mg} / 100 \mathrm{ml})$.

Eleven months after transplantation, and after two months of amenorrhoea she aborted spontaneously a hydatidiform mole. Despite uterine curettage on three subsequent occasions, serum chorionic gonadotrophin concentrations remained raised (up to $100000 \mathrm{IU} / \mathrm{l}$ ). There was no evidence of extra uterine trophoblastic disease. She was referred for cytotoxic chemotherapy. During the first course of low dose methotrexate she developed acute abdominal pain, paralytic ileus, and became shocked. Emergency laparotomy showed rupture of the uterus, and a total abdominal hysterectomy was performed. Serum chorionic gonadotrophin values rapidly returned to normal postoperatively and remained so.

Gross examination of the specimen showed a fundal mass with an overlying tear. Histological study showed villi with pronounced trophoblastic proliferation. There was invasion of the uterine muscle and extensive permeation of vessels (figure) by atypical trophoblast. There were features of an invasive mole with possible incipient evolution into choriocarcinoma.

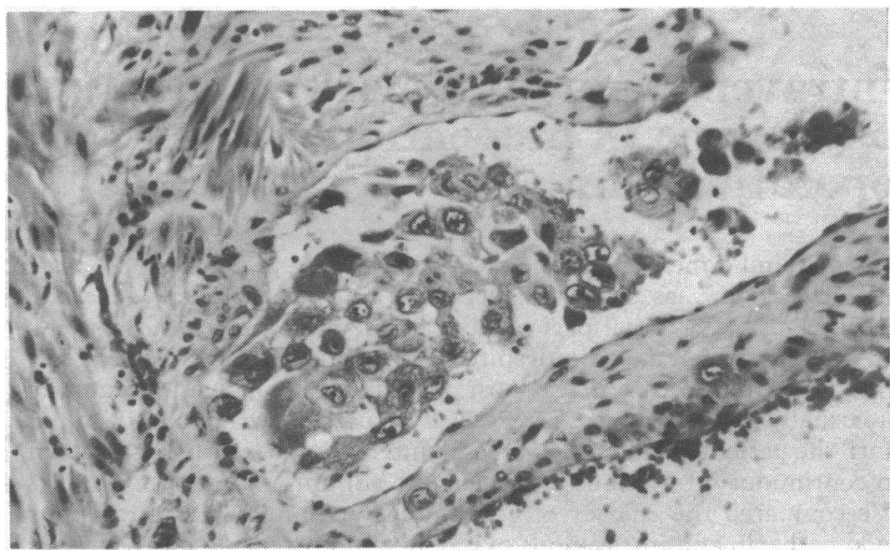

Uterine vein invaded by atypical trophoblast cells. Haematoxylin and eosin $\times 215$ (original magnification)

\section{Comment}

Patients with renal transplants have an increased incidence of malignant disease. ${ }^{2}$ A proposed reactivation of latent choriocarcinoma has been described after renal transplantation, ${ }^{3}$ as has transmission of choriocarcinoma with the cadaver kidney, but no gestational trophoblastic disease arising de novo in a pregnant transplant recipient has been noted.

Gestational trophoblastic disease has a range of malignant potential from hydatidiform mole and invasive mole to choriocarcinoma. The clinical course is determined by factors such as the inherent malignant potential of the trophoblastic tumour and the immunological host response. ${ }^{5}$

In $80 \%$ of cases of classic hydatidiform mole human chorionic gonadotrophin concentrations become normal within 60 days of removal of the tumour, reflecting effective host immunological rejection mechanisms. ${ }^{5}$ The trophoblastic disease in our patient increased in malignant potential from the initial hydatidiform mole. It may be postulated that transformation occurred because of immunosuppression of the host, induced to prevent rejection of the transplanted kidney. 
If this is so we may expect an increase in incidence of this malignancy in the future in women with renal transplants who become pregnant.

We thank Mr J Peck, Dr A Davison, Mr D Millar, Dr F E Neal, Dr G Pennington, Mr P Corbett, and Mr P Guillou for their contributions towards the management of this patient and their permission to report the case.

${ }^{1}$ Registration Committee of the European Dialysis and Transplant Association. Successful pregnancies in women treated by dialysis and kidney transplantation. Br $\mathcal{F}$ Obstet Gynaecol 1980;87:839-45.

${ }^{2}$ Penn 1. Malignancies associated with renal transplantation. Urology $1977 ; 10$, suppl:57-63.

${ }^{3}$ Lelièvre G, Ribet $M$, Gosselin B, Dequiedt Ph, Lepoutre E, Tacquet A. Chorio-carcinoma après transplantation. I Urol Nephrol (Paris) 1978; 84:345-6.

${ }^{4}$ Gokel JM, Rjosk HK, Meister P, Stelter WJ, Witte J. Metastatic choriocarcinoma transplanted with cadaver kidney: a case report. Cancer 1977;39:1317-21.

${ }^{5}$ Patillo RA. Immunology of gestational trophoblastic neoplasms. Semin Oncol 1982;9:157-62.

(Accepted 7 fune 1983)

Weston Park Hospital, Sheffield S10 2S J

I H MANIFOLD, MA, MRCP, senior registrar

A E CHAMPION, MRCP, FRCR, senior registrar

J R GOEPEL, MB, MRCPATH, consultant pathologist

Jessop Hospital, Sheffield

S RAMSEWAK, MB, MRCOG, senior house officer

St James's University Hospital, Leeds

P E MAYOR, BSC, MRCP, registrar

Correspondence to: Dr I H Manifold.

\section{Intravenous indomethacin or oxycodone in prevention of post- operative pain}

It is an indictment of modern medicine that prevention of postoperative pain has been neglected. ${ }^{1}$ Pain seems to be generally accepted as an essential part of the postoperative phase, and patients may suffer intolerable pain despite the plethora of effective analgesics available. Opiates are still the most popular potent analgesics, but they are usually not administered frequently enough or are not administered until the patient complains: Increased interest has recently been shown in continuous intravenous or on demand administration of opiates. ${ }^{2-4}$ We compared the efficacy of continuously administered intravenous indomethacin and intravenous oxycodone in preventing postoperative pain.

\section{Patients, methods, and results}

Altogether 168 patients ( 124 women, 44 men) received a single dose of $0.5 \%$ bupivacaine as an epidural anaesthetic before operation for varicose veins or orthopaedic disorders. Immediately after the operation 148 patients were given $25 \mathrm{mg}$ indomethacin (Confortid IV, A/S Dumex, Denmark) and 20 were given $5 \mathrm{mg}$ oxycodone (Oxanest, Leiras, Finland) intravenously over 10 minutes. Thereafter indomethacin $(5 \mathrm{mg} / \mathrm{h})$ and oxycodone $(2 \mathrm{mg} / \mathrm{h})$ were given as continuous injections by means of an automatic syringe pump (Hostec R-50, Finland) throughout the night after the operation. Supplementary doses of $10 \mathrm{mg}$ indomethacin or $2 \mathrm{mg}$ oxycodone were administered intravenously to patients who complained of pain. A five degree scale of pain (none, mild, moderate, severe, or intolerable) on a time schedule was used to record pain and its duration. Possible side effects were recorded. Patients were questioned about their pain on the morning after the operation.

The table shows the incidence and relative duration of pain with each drug. The mean dose of indomethacin was $123 \mathrm{mg}$ and of oxycodone $38.1 \mathrm{mg}$. Forty one $\left(27 \cdot 7 \%_{1}\right)$ of the patients given indomethacin and eight $(40 \%)$ given oxycodone received supplementary doses of their respective drugs. The incidence of no pain was significantly higher $(p<0.01)$ and the incidence of severe pain significantly lower in patients given indomethacin $(p<0.01)$.

Side effects comprised mild nausea (17 patients $\left(11.5^{\circ}\right)$ given indomethacin $v$ four $(20 \%)$ given oxycodone), vomiting (three $(2 \%) v$ three $(15 \%))$, and mild dizziness (seven $\left(4 \cdot 7{ }^{\circ},\right) v$ seven $(35 \%)$ ). Patient acceptance of the treatment was high: 143 patients $(97 \%)$ given indomethacin and 19 $(95 \%)$ given oxycodone found it acceptable.

\section{Comment}

The lower incidence of postoperative pain and the longer periods without pain ( $p<0.01$ and $p<0.05$, respectively) in patients given indomethacin show that indomethacin prevented postoperative pain more effectively than oxycodone. The mean dose of indomethacin was only $123 \mathrm{mg}$ whereas that of oxycodone was $38 \cdot 1 \mathrm{mg}$, which is almost the maximum daily dose.

Because of its mechanism of action and other properties it seems logical to administer indomethacin prophylactically and then to maintain a preventive concentration by continuous intravenous injection. An initial intravenous dose of $25 \mathrm{mg}$ and a maintenance dose of $5 \mathrm{mg} / \mathrm{h}$ are low enough to permit additional doses when necessary. This regimen resulted in a peak serum concentration of about $2 \mathrm{mg} / \mathrm{l}$ and a steady state concentration of about $0.7 \mathrm{mg} / \mathrm{l}$. Indomethacin has the added advantage of being non-addictive.

The type of surgery that these patients had undergone was theoretically suitable for comparing analgesia obtained with an antiinflammatory agent and with oxycodone. In more severe and deeper pain intravenous indomethacin may be administered together with intravenous opiates because of their advantageous synergism. ${ }^{5}$

${ }^{1}$ Anonymous. Postoperative pain [Editorial]. Br Med f 1976;i:1491.

2 Rutter PC, Murphy F, Dudley HAF. Morphine: controlled trial of different methods of administration for post-operative pain relief. $\mathrm{Br}$ Med F 1980;i:12-3.

${ }^{3}$ Church JJ. Continuous narcotic infusions for relief of post-operative pain. Br Med f 1979;i :977-9.

4 Nayman J. Measurement and control of post-operative pain. Ann R Coll Surg Engl 1979;61:419-26.

${ }^{5}$ Reasbeck PG, Rice ML, Reasbeck JC. Double-blind controlled trial of indomethacin as an adjunct to narcotic analgesia in major abdominal surgery. Lancet 1982 ;ii:115-8.

(Accepted 10 fune 1983)

Kuopio University Central Hospital, Department of Anaesthesiology, 70210 Kuopio 21, Finland

MATTI A K MATTILA, MD, lecturer in anaesthesiology

EVA AHLSTRÖM-BENGS, research assistan

PENTTI PEKKOLA, MD, research assistant

Correspondence to: Dr M A K Mattila.

Incidence and duration of post-operative pain in patients given intravenous indomethacin or oxycodone

\begin{tabular}{|c|c|c|c|c|c|c|}
\hline \multirow{2}{*}{ Degree of pain* } & \multicolumn{2}{|c|}{ No $(\%)$ of patients given: } & \multirow{2}{*}{$\mathbf{P} \dagger$} & \multicolumn{2}{|c|}{$\begin{array}{l}\text { Duration of pain as } \% \text { of } \\
\text { total duration of treatment }\end{array}$} & \multirow{2}{*}{$\mathrm{P}+$} \\
\hline & Indomethacin & Oxycodone & & Indomethacin & Oxycodone & \\
\hline $\begin{array}{l}\text { None } \\
\text { Mild } \\
\text { Moderate } \\
\text { Severe } \\
\text { Intolerable }\end{array}$ & $\begin{array}{c}103(69 \cdot 6) \\
18(12 \cdot 2) \\
22(14 \cdot 9) \\
4(2 \cdot 7) \\
1(0 \cdot 6)\end{array}$ & $\begin{array}{l}8(40) \\
6(30) \\
3(15) \\
3(15)\end{array}$ & $\begin{array}{l}<0.01 \\
<0.05 \\
\text { NS } \\
<0.01 \\
\text { NS }\end{array}$ & $\begin{array}{l}97 \cdot 1 \\
1.6 \\
1 \cdot 1 \\
0 \cdot 2 \\
0 \cdot 04\end{array}$ & $\begin{array}{r}90.0 \\
5.0 \\
2.5 \\
2.5\end{array}$ & $\begin{array}{l}<0.05 \\
\text { NS } \\
\text { NS } \\
\text { NS } \\
\text { NS }\end{array}$ \\
\hline Total & $148(100)$ & $20(100)$ & & 100 & 100 & \\
\hline
\end{tabular}

* Incidence of pain was registered according to hardest pain.

$\dagger \chi^{2}$ test. 